\title{
BUSINESS STRATEGY, KNOWLEDGE MANAGEMENT DAN CORPORATE SOCIAL PERFORMANCE DALAM MEMPENGARUHI ECONOMIC PERFORMANCE
}

\author{
Arry Eksandy ${ }^{(1)}$ \\ Universitas Muhammadiyah Tangerang \\ arry.eksandy@yahoo.com \\ Riski Ulan Sari ${ }^{(2)}$ \\ Universitas Muhammadiyah Tangerang \\ riskiulan4@gmail.com \\ Vianty Dewi Rengganingsih ${ }^{(3)}$ \\ Universitas Muhammadiyah Tangerang \\ vianty.dewi89@gmail.com
}

\begin{abstract}
This research aims to determine the effect of business strategy, knowledge management and corporate social performance on economic performance partially on companies manufacture during the period 2014-2018.

The population in this research is all companies manufacture listed on Indonesia Stock Exchange during the period 2014-2018. The total samples tested were 15 companies selected by purposive sampling technique. Data type in this research use secondary data obtained from Indonesia Stock Exchange and site respectively of company being sampled. Data analysis technique use panel data regression with Eviews 9.0 program.

The result indicates that business strategy have no effectt on economic performance. Knowledge Management have a positive effect on economic performance. And Corporate Social Performance have no effect on economic performance.
\end{abstract}

Keywords: Economic performance, Business Strategy, Knowledge Management, Corporate Social Performance.

\section{PENDAHULUAN}

Seiring dengan perkembangan arus globalisasi dan teknologi seperti sekarang ini, Indonesia sebagai Negara berkembang telah mengalami perubahanperubahan yang cukup pesat, baik itu perubahan kecil maupun perubahan besar. Dilihat dari segi ekonomi yang kini mulai menerapkan sistem politik luar negeri bebas aktif, dimana bangsa asing semakin banyak melakukan kerja sama dengan Indonesia di segala bidang terutama pada bidang ekonomi sehingga saat ini Indonesia sudah mulai bisa menambah pasar internasional barang jadi atau jasa yang indonesia miliki dan indonesia ciptakan bisa terkenal dan di akui oleh berbagai negara. Salah satu sektor penting dalam bidang ekonomi terdapat dalam sektor industri manufaktur.

Kementerian Perindustrian memperlihatkan data World Bank tahun 2017, bahwa saat ini negaranegara industri di dunia, kontribusi sektor manufakturnya terhadap perekonomian rata-rata sekitar 17\% (okezone.com diakses pada 22 April 2019). Indonesia dinilai perlu mengembangkan industri manufaktur agar produktivitas dapat bertambah, kinerja ekonomi dapat meningkat, dan dapat menyediakan lapangan kerja. Indonesia dalam sektor industri dinilai tumbuh relatif rendah dibandingkan sektor-sektor lainnya yang mampu tumbuh lebih cepat. Padahal, untuk mendorong produktivitas sebuah negara agar menjadi negara maju, sektor industri harus didorong agar nilai tambah dalam meningkatkan kinerja ekonomi disuatu Negara menjadi lebih tinggi. Salah satu penyebab rendahnya sektor industri dapat dilihat melalui adanya penurunan return tahunan atau return saham dari perusahaan manufaktur.

Kinerja ekonomi diungkapkan dalam laporan keuangan perusahaan yang dikeluarkan secara periodik yang memberikan suatu gambaran tentang posisi keuangan perusahaan. Informasi yang 
terkandung dalam laporan keuangan digunakan oleh investor untuk memperoleh perkiraan tentang laba dan dividen di masa mendatang dan resiko atas penilaian tersebut (Kusuma et al., 2014). Tuntutan economic performance berimplikasi pada perwujudan aktivitas industri sebagai interaksi harmonis antara stakeholders (pihak-pihak yang berkepentingan) dengan shareholders atau para pelaku bisnis itu sendiri. Semakin etis para pelaku bisnis, maka tujuan perusahaan akan tercapai dengan sendirinya dan bisnisnya akan berjalan dalam koridor yang diharapkan. Perilaku kinerja ekonomi yang bersifat etis, yaitu dengan mewujudkan tanggung jawab sosial perusahaan (Haholongan, 2016).

Kinerja ekonomi perusahaan dapat dilihat melalui Return Saham tahunan yang ada didalam perusahaan, kinerja tersebut dilihat dari sudut pandang pasar modal melalui return saham tahunan atau tingkat pengembalian saham atas investasi yang dilakukan oleh investor. Kinerja ekonomi dapat dinilai semakin baik apabila tingkat pengembalian atas saham tersebut baik, yang dapat memberikan kepercayaan yang tinggi kepada investor untuk menginvestasikan sahamnya di perusahaan terkait hal ini dapat memberikan sinyal kepada para calon investor untuk menanamkan sahamnya sehingga hal tersebut dapat memberikan kemudahan untuk perusahaan dalam memperoleh tambahan modal untuk kegiatan operasional.

Terdapat faktor-faktor yang mempengaruhi economic performance diantaranya business strategy, knowledge management dan Corporate Social Performance. Berbicara tentang peranan manajer tidak terlepas dari peranan mereka dalam menentukan strategi bisnis perusahaan. Dalam kapasitasnya sebagai penyedia laporan keuangan di satu sisi sebagai penentu strategi bisnis perusahaan, maka kualitas laba yang ada di perusahaan secara potensial juga merupakan fungsi dari strategi bisnis (Widyasari et al, 2017). Strategi bisnis perusahaan mempengaruhi seluruh aktivitas perusahaan karena semua aktivitas proses bisnis, kegiatan operasional, dan transaksi yang dilakukan serta segala keputusan bisnis dibuat oleh manajer harus sejalan dengan strategi bisnis (Arieftiara et al, 2013).

Tipologi dari (Miles et al., 1978) mampu memberikan karakter mengenai organisasi sebagai sebuah sistem yang lengkap, khususnya terkait dengan orientasi strategi. (Miles et al., 1978) membagi strategi bisnis perusahaan ke dalam 4 kategori berdasarkan orientasi pasarnya, yaitu prospector, defender, analyzer dan reactor. Pengelompokkan strategi tersebut dengan cara penggunaan skor yang telah ditentukan. Prospector adalah perusahaan yang memiliki komitmen terhadap inovasi dan mencari peluang pasar yang baru. Defender berfokus pada efisiensi dan bukan pada inovasi (Wardani \& Isbela, 2017). Defender lebih ditekankan pada penggunaan strategi stabilitas dan kelangsungan hidup perusahaan tanpa banyak melakukan perubahaan, karena itu lebih terfokus pada stabilitas jangka panjang. Analyzer adalah perusahaan yang menggunakan strategi diantara defender dan prospectors. Artinya perusahaan ini tidak terlalu berani mengambil resiko besar dalam berinovasi, tetapi tetap berusaha menciptakan keunggulan dalam pelayanannya kepada pasar. Reactor adalah jenis perusahaan yang lebih banyak ditekan oleh lingkungan, karena kurang memerhatikan adanya perubahan lingkungan dan sistem persaingan. Perusahaan jenis ini lebih mementingkan efisiensi, menekan biaya termasuk menekan pada sumberdaya manusia.

Dari pemaparan mengenai dua tipe strategi bisnis menurut Miles dan Snow (1978) tersebut diketahui memang strategi bisnis defender dan prospector memiliki arah yang sangat berbeda dalam meningkatkan kinerja ekonomi dari sebuah perusahaan. Strategi defender misalnya apabila perusahaan lebih memilih melakukan strategi bisnis defender dengan mengeluarkan produk yang mengikuti pangsa pasar pesaing maka hal ini dapat menguntungkan dari segi kestabilan perusahaan dimata para investornya. Namun jika perusahaan memilih melakukan strategi bisnis prospector yang berinovasi dalam menciptakan produknya yang tidak sama dengan pangsapasar pesaing hal ini diperbolehkan, namun memiliki resiko yang tinggi yang apabila inovasi baru itu dikeluarkan dan tidak diterima oleh pangsa pasarnya maka perusahaan harus siap menanggung resiko yang tidak diinginkan tetapi jika inovasi tersebut diterima di pangsa pasarnya maka hal ini dapat menguntungkan untuk perusahaan dan meningkatkan economic performance (kinerja ekonomi) perusahaan, apalagi jika inovasi tersebut dapat menjadikan perusahaan menjadi perusahaan yang mendominasi pangsa pasar dengan produk sejenis. 
Menurut Wulantika (2017) Knowledge Management merupakan kegiatan organisasi dalam mengelola pengetahuan sebagai aset, dimana dalam berbagai strateginya ada penyaluran pengetahuan yang tepat kepada orang yang tepat dan dalam waktu yang cepat, hingga mereka bisa saling berinteraksi, berbagi pengetahuan dan mengaplikasikannya dalam pekerjaan sehari-hari demi peningkatan kinerja organisasi.

Kemampuan suatu lembaga atau institusi akan ilmu pengetahuan dan teknologi dalam era globalisasi sekarang ini menjadi salah satu faktor daya saing yang sangat penting. Ketika suatu institusi atau lembaga ingin meningkatkan kualitasnya, maka dibutuhkan tingkat pengetahuan yang sangat luas pada berkompetisi dan menunjukkan eksistensinya. Kondisi kompetisi yang semakin ketat seperti sekarang ini menyebabkan perlu adanya perubahan paradigma dari resource-based competitivenes menjadi mengandalkan knowledge-based competitivenes. Kedua konsep ini sangat bertolak belakang, dimana konsep pertama bertumpu pada sumber daya alam, lokasi dan kondisi geografis. Sedangkan konsep yang kedua berdasarkan pada ilmu pengetahuan dan teknologi (IPTEK) serta pengembangan sumber daya manusia (SDM). Untuk memudahkan pengembangan sumber daya manusia suatu lembaga diperlukan kemampuan untuk mengelola dan mengembangkan knowledge yang dimiliki. Pengelolaan pengetahuan (knowledge management) tersebut pada akhirnya dapat menjadi dukungan yang handal bagi suatu lembaga untuk meningkatkan daya saingnya. Perusahaan perlu mengelola pengetahuan yang dimiliki apabila ingin mencapai visi dan misinya agar dapat bersaing dengan perusahaan lain. Penerapan knowledge management merupakan salah satu cara perusahaan untuk menghadapi persaingan dan tuntutan yang semakin tinggi agar dapat meningkatkan kinerja manajemen dalam mengelola perusahaan.

Tujuan utama perusahaan yaitu memaksimalkan keuntungan. Beberapa perusahaan merasa bahwa dengan melakukan kegiatan sosial dan lingkungan justru akan menambah pengeluaran perusahaan dan mengurangi keuntungan. Seiring berjalannya waktu, peran perusahaan dalam hal tanggung jawab sosial saat ini menjadi cukup penting untuk dipertimbangkan (Wibisono et al., 2014). Perusahaan yang memiliki corporate social performance (CSP) yang tinggi akan memperoleh kepercayaan yang lebih tinggi dari para stakeholder perusahaan, karena para stakeholder memiliki anggapan apabila perusahaan dengan kinerja sosial yang tinggi akan memiliki kinerja ekonomi yang lebih baik dan berdampak pada return yang akan diperoleh dari investasi yang dilakukan para stakeholder dibandingkan dengan perusahaan yang memiliki kinerja sosial yang lebih rendah.

Kinerja ekonomi dapat menggambarkan suatu kinerja perusahaan secara umum Beberapa hasil penelitian empiris menemukan bahwa tidak ada hubungan antara kinerja sosial dengan kinerja keuangan (netral). Pihak-pihak yang menghasilkan pandangan ini berargumen bahwa ada sangat banyak variabel antara kinerja sosial dan kinerja keuangan, sehingga tidak ada alasan untuk mengharapkan terjadinya hubungan antara dua hal tersebut. Di sisi lain, pihak yang berpendapat bahwa corporate social performance (CSP) akan berpengaruh positif bagi perusahaan juga memiliki argumen kuat. Menurut (Rosyid, 2015) dengan corporate social performance (CSP) yang baik akan meningkatkan kinerja perusahaan, sehingga perusahaan-perusahaan yang menghasilkan biaya besar untuk kegiatan sosial bagi masyarakat luas hendaklah tidak usah risau dan kecewa karena biaya besar yang mereka keluarkan akan berdampak positif bagi kinerja ekonominya.

\section{KAJIAN PUSTAKA DAN PENGEMBANGAN HIPOTESIS}

\section{Teori Stewardship}

Teori stewardship ini menyatakan bahwa tidak ada hubungannya permasalahan umum yang terjadi dengan motivasi manajemen. Mengingat tidak adanya permasalahan motivasi internal di kalangan eksekutif, pertanyaannya tentang seberapa jauh eksekutif dapat mencapai kinerja perusahaan yang baik yang mereka cita-citakan. Dengan demikian, teori stewardship ini terjadi karena terdapat perbedaan kinerja yang timbul dari situasi struktural dimana manajemen eksekutif mempermudah tindakannya yang efektif (Donaldson dan Davis, 1991). Masalah yang terjadi apakah struktur organisasi membantu eksekutif untuk merumuskan dan menerapkan rencana untuk kinerja perusahaan yang baik (Donaldson 1985). Struktur ini akan mempermudah tujuan sejauh mereka memberikan ekspektasi yang jelas dan konsisten serta memberi 
wewenang dan memberdayakan manajemen senior (Donaldson dan Davis, 1991).

\section{Teori Akuntansi Positif}

Teori ini dipelopori oleh Watts dan Zimmerman (1990) yang memaparkan bahwa faktorfaktor ekonomi tertentu bisa dikaitkan dengan perilaku manajer atau para pembuat laporan keuangan. Ada tiga hipotesis khusus yang paling sering diuji adalah the bonus plan hypothesis, the debt or equity hypothesis, dan the poitical cost hypothesis. Hubungan teori akuntansi positif dengan economic performance terletak pada sikap manajemen yang berupaya untuk menggunakan kemampuan, pengetahuan akuntansi, kebijakan akuntansi untuk melihat pandangan kedepan mengenai kinerja ekonomi yang akan terjadi dimasa mendatang yang didasari oleh ketiga hipotesis dalam teori akuntansi positif tersebut.

\section{Teori Stakeholder}

Teori stakeholder adalah teori yang menggambarkan kepada pihak mana saja perusahaan bertanggungjawab (Freeman \& Reed, 1983). Stakeholders merupakan semua pihak baik internal maupun eksternal yang mempunyai hubungan yang bersifat mempengaruhi maupun dipengaruhi, bersifat langsung maupun tidak langsung oleh perusahaan. Batasan stakeholders tersebut mengisyaratkan bahwa perusahaan hendaknya memperhatikan stakeholders, karena mereka adalah pihak yang dipengaruhi dan mempengaruhi baik langsung maupun tidak langsung atas aktivitas serta kebijakan yang diambil oleh perusahaan. Jika perusahaan tidak memperhatikan stakeholders bukan tidak mungkin akan menuai protes dan dapat mengeleminasi legitimasi stakeholders (Adams, 2002).

Teori ini dihubungkan dengan dua variabel.

Pengetahuan merupakan aset yang harus dimanfaatkan oleh perusahaan guna mencapai kepentingan perusahaan dan para stakeholder. Pihak stakeholder internal turut berperan aktif dalam mengelola manajemen perusahan agar dengan keikutsertaannya dalam mengelola manajemen pengetahuan dan meningkatkan mutu pengetahuan di dalam organisasi itu sendiri sehingga dapat meningkatkan kinerja manajemen. Dengan meningkat nya kinerja manajemen akan mempengaruhi stakeholder dari eksternal sehingga stakeholder eksternal yakin bahwa perusahaan tersebut bisa bersaing dalam era globalisasi seperti saat ini dapat berpartisipasi dalam mengembangkan knowledge management diperusahaan agar tercapainya tujuan dan dapat bersaing didalam era globalisasi seperti saat ini.

Penerapan Corporate Social Performance dapat menjadi strategi perusahaan untuk memenuhi kepentingan dari para stakeholder akan informasi non keuangan perusahaan terkait dampak sosial dan lingkungan yang timbul dari adanya aktivitas perusahaan. Semakin baik penerapan Corporate Social Performance oleh perusahaan akan membuat stakeholder memberikan dukungan penuh kepada perusahaan atas segala aktivitasnya yang bertujuan untuk meningkatkan kinerja dan mencapai laba yang diharapkan dan juga meningkatkan kesejahteraan bagi karyawan, pelanggan, dan masyarakat lokal. Sehingga diharapkan terjalin hubungan yang baik antara perusahaan dengan lingkungan sekitar.

\section{Economic Performance}

Economic Performance adalah suatu usaha formal yang dilaksanakan perusahaan untuk mengevaluasi efisien dan efektivitas dari aktivitas keuangan perusahaan yang telah dilaksanakan pada periode waktu. Kinerja ekonomi dapat diukur dari laporan keuangan perusahaan (financial reports) yang dikeluarkan secara periodik yang memberikan suatu gambaran tentang posisi keuangan perusahaan. Informasi yang terkandung dalam laporan keuangan digunakan oleh investor untuk memperoleh perkiraan tentang laba dan dividen di masa mendatang dan resiko atas penilaian tersebut (Kusuma et al., 2014).

\section{Business Strategy}

Business strategy merupakan strategi atau rencana yang menyeluruh dalam rangka pencapaian tujuan perusahaan. Bagi perusahaan, strategi diperlukan tidak hanya untuk memperoleh profit, tetapi juga untuk mempertahankan kelangsungan hidup perusahaan di masa yang akan datang (Sule \& Saefullah, 2017). Menurut Porter (1985) Strategi adalah tentang membuat pilihan. Penggunaan strategi merupakan cara untuk memastikan sebuah keunggulan kompetitif berkelanjutan dengan menginvestasikan sumber daya yang dibutuhkan untuk mengembangkan kapabilitas, dan jika suatu keunggulan berkelanjutan, itu akan mengarah pada kinerja yang unggul untuk jangka panjang (Lin et al., 2014). 
Miles dan Snow (1978) membedakan strategi berdasarkan proses adaptasi organisasi terhadap perubahan lingkungannya, dan empat tipologi strategi yaitu prospector, defender, analyzer dan reactor.

\section{Knowledge Management}

Menurut Wiig (1993) Knowledge Management yaitu manajemen yang berfokus pada pengembangan organisasi dalam rangka menginvestasikan dan mengeksploitasi pengetahuan. Strategi, produk dan jasa, aliansi, dan akuisisi atau divestasi perusahaan harus mempertimbangkan pengetahuan yang terkait dengan kepentingan bisnisnya.

Michael Polanyi pertama kalinya membedakan konsep pengetahuan menurut jenis dan kemudahan pengungkapannya. (Polanyi, 1958) membagi pengetahuan menjadi dua jenis, yaitu pengetahuan eksplisit (explicit knowledge) dan pengetahuan tacit (tacit knowledge). Pengetahuan eksplisit adalah pengetahuan yang tertulis, tercatat, teratur, objektif, rasional, dan teknis. Pengetahuan tacit adalah personal know-how yang merupakan pengetahuan yang berada dalam domain subjektif, kognitif, pengalaman, perasaaan, dan sulit diungkapkan.

Sejumlah teknik pengukuran Knowledge Management cukup canggih tersedia saat ini. Selain itu, juga tersedia alat-alat yang dapat membantu menilai seberapa baik perusahaan mengalami kemajuan. Alat-alat tersebut mencakup Penyusunan Patok Duga (Benchmarking), Balanced Scorecard Method, Metode Rumh Kualitas dan Result-based Management and Accountability Framework (RMAF).

\section{Corporate Social Performance}

Menurut Carroll (1979) Corporate Social Performance adalah konstruksi multidimensi yang terdiri dari tanggung jawab ekonomi kepada investor dan konsumen, tanggung jawab etika kepada masyarakat, tanggung jawab hukum kepada pemerintah atau hukum, dan tanggung jawab terhadap masyarakat.

Tujuan utama perusahaan yaitu memaksimalkan keuntungan. Beberapa perusahaan merasa bahwa dengan melakukan kegiatan sosial dan lingkungan justru akan menambah pengeluaran perusahaan dan mengurangi keuntungan. Seiring berjalannya waktu, peran perusahaan dalam hal tanggung jawab sosial saat ini menjadi cukup penting untuk dipertimbangkan (Wibisono et al., 2014).

\section{Pengaruh Business Strategy Terhadap Economic Performance}

Business Strategy merupakan perencanaan terintegrasi dengan mempertimbangkan aspek strategik dalam perusahaan (Paylosa, 2014). Penggunaan strategi merupakan cara untuk memastikan sebuah keunggulan kompetitif berkelanjutan dengan menginvestasikan sumber daya yang dibutuhkan untuk dikembangkan (Lin et al., 2014).

(Houqe et al., 2013) mendefinisikan strategi sebagai determinasi dari tujuan jangka panjang dari suatu perusahaan. Beberapa pertanyaan belum terjawab mengenai mengapa beberapa perusahaan berkinerja lebih bagus daripada perusahaan lain sedangkan mereka dalam industri dan kondisi yang sama (Sarac et al., 2014). Oleh karena itu strategi bisnis perusahaan dan sumber daya mulai dipertimbangkan sebagai faktor penting dalam hal memperngaruhi kinerja perusahaan (Porter, 1985). Tipe strategi bisnis yang tepat akan menciptakan kinerja yang superior bagi perusahaan.

Hasil penelitian (Puspita, 2018) menjelaskan bahwa strategi bisnis berpengaruh terhadap kinerja perusahaan. Sesuai dengan keunggulan bersaing, bahwa keunggulan bersaing adalah keunggulan posisi dalam persaingan industri. Strategi bisnis adalah alat yang tepat dalam menciptakan keunggulan bersaing. Keunggulan bersaing diciptakan dan memiliki sumber daya khas dan efisiensi sumber daya agar perusahaan dapat lebih unggul daripada pesaingnya dalam hal mendapatkan laba yang tinggi. Hasil yang serupa ditemukan oleh (Ajagbe et al., 2016) yang menjelaskan strategi bisnis berkontribusi terhadap kinerja organisasi. Lingkungan bisnis yang sangat kompetitif, didorong oleh teknologi dan pengetahuan menjadikannya penting bagi manajer bisnis untuk mengembangkan arahan yang jelas dalam bentuk strategi bisnis yang tepat yang akan mendorong kinerja organisasi yang lebih tinggi bagi perusahaan untuk mencapai sasaran yang diinginkan. Berdasarkan uraian diatas, penelitian ini mengajukan hipotesis sebagai berikut:

$\mathrm{H}_{1}$ : Business Strategy Berpengaruh Positif Terhadap Economic Performance. 


\section{Pengaruh Knowledge Management Terhadap Economic Performance}

Dalam era berbasis pengetahuan, kini pengetahuan dipandang sebagai sumber daya strategis utama untuk kelangsungan hidup organisasi. Knowledge management ialah suatu fungsi yang membentuk, mengidentifikasi dan mengelola pengetahuan organisasi untuk keuntungan jangka panjang (Darroch, 2003).

Sebuah organisasi sangat dipengaruhi oleh sumber daya pengetahuan. Dimana pengetahuan itu akan menjadi aset sebuah organisasi dalam perusahaan yang akan memunculkan ide-ide baru sehingga knowledge management akan memiliki pengaruh terhadap kinerja organisasi, karena manajemen pengetahuan bermanfaat bagi manajemen dalam organisasi untuk mengambil sebuah keputusan (Salama, 2017).

Penelitian yang dilakukan oleh (Sahas \& Falah, 2017) menjelaskan bahwa knowledge management berpengaruh positif signifikan terhadap kinerja perusahaan. Ia menjelaskan bahwa peran knowledge management semakin penting dalam perusahaan karena sebagai alat untuk memfasilitasi interaksi yang lebih baik melalui ketersediaan arus informasi, hal ini baik guna menjadi organisasi pembelajar. Berdasarkan uraian diatas, penelitian ini mengajukan hipotesis sebagai berikut:

$\mathrm{H}_{2}$ : Knowledge Management Berpengaruh Positif Terhadap Economic Performance.

\section{Pengaruh Corporate Social Performance Terhadap Economic Performance}

Corporate Social Performance (CSP) didefinisikan sebagai sebuah konfirgurasi organisasi bisnis dari prinsip tanggungjawab sosial, merespon sosial dan kebijakan-kebijakan, program-program, dan menampakkan hasil seperti mereka menguhubungkan untuk hubungan sosial perusahaan (Wirawan, 2016). Perusahaan yang memiliki tanggung jawab sosial yang baik akan mendapatkan apresiasi positif dari stakeholder, sehingga perusahaan dapat meningkatkan penjual dan mengurangi biaya yang berujung pada meningkatnya profit perusahaan (Eduardus \& Juniarti, 2016).

Corporate Social Performance memiliki pengaruh terhadap economic performance apabila perusahaan yang memiliki tingkat kepercayaan yang baik di hadapan pihak pemegang saham yaitu perusahaan telah memiliki tanggungjawab, menerapkan dan mengungkapkan Corporate Social Performance dalam laporan keuangan akan direspon positif oleh investor melalui fluktuasi harga saham perusahaan, maka akan membuat citra perusahaan baik di hadapan investor. Dan investor cenderung akan tertarik untuk menanamkan modalnya pada perusahaan yang memiliki standart tinggi dalam masalah sosial dan akan meningkatkan economic performance.

Penelitian yang dilakukan oleh (Rosyid, 2015) menemukan bahwa kinerja sosial berpengaruh positif terhadap kinerja keuangan. Dengan melakukan Corporate Social Performance diharapkan dapat memberikan bukti nyata bahwa proses produksi yang dilakukan perusahaan tidak hanya berorientasi keuntungan, tetapi juga memperhatikan isu sosial, dan lingkungan, sehingga dapat meningkatkan kepercayaan stakeholder yang akan berdampak pada peningkatan nilai perusahaan.

$\mathrm{H}_{3}$ : Corporate Social Performance Berpengaruh Positif Terhadap Economic Performance.

\section{METODE PENELITIAN}

Dalam penelitian ini menggunakan data sekunder berupa laporan keuangan dan laporan tahunan.

Populasi dari penelitian ini adalah perusahaan Manufaktur yang terdaftar di Bursa Efek Indonesia (BEI). Periode penelitian mencangkup data pada tahun 2014 sampai dengan tahun 2018. Teknik pengambilan sampel yang digunakan adalah non probality sampling dengan metode purposive sampling. Berikut kriteria pemilihan sampel yang digunakan:

\begin{tabular}{|c|l|c|}
\hline No & \multicolumn{1}{|c|}{ Kriteria } & Jumlah \\
\hline 1. & $\begin{array}{l}\text { Perusahaan Manufaktur yang terdaftar selama } \\
\text { periode 2014-2018 }\end{array}$ & 167 \\
\hline 2. & $\begin{array}{l}\text { Perusahaan manufaktur yang tidak } \\
\text { menerbitkan laporan keuangan berturut-turut } \\
\text { selama periode penelitian 2014-2018 }\end{array}$ & $(60)$ \\
\hline 3. & $\begin{array}{l}\text { Perusahaan yang tidak menggunakan mata } \\
\text { uang rupiah }\end{array}$ & $(26)$ \\
\hline 4. & $\begin{array}{l}\text { Perusahaan yang tidak melakukan pembagian } \\
\text { dividen selama periode pengamatan }\end{array}$ & $(66)$ \\
\hline Jumlah Perusahaan yang menjadi sampel penelitian & 15 \\
\hline \multicolumn{2}{|l|}{ Jumlah Periode Penelitian (tahun) } & 5 \\
\hline \multicolumn{2}{|l}{ Jumlah Data Observasi Penelitian } \\
\hline
\end{tabular}




\section{Definisi Operasional dan Pengukuran Variabel Economic Performance (Variabel Dependen)}

Menurut Al-Tuwaijri, et al. (2003) penelitianpenelitian sebelumnya menggunakan ukuran accounting-based dan market-based untuk mempresentasikan economic performance, pada penelitian ini digunakan ukuran market-based untuk mempresentasikan economic performance yaitu dengan cara menggunakan industry-adjusted annual return yang didasarkan pada perhitungan selisih antara annual stock return dengan median dari kumpulan data annual stock return yang dianggap mampu mempresentasikan economic performance secara lebih objektif dan komprehensif (Widarto, 2015). Economic performance dinyatakan dalam skala yang dihitung:

$$
\mathrm{EcP}=\frac{\left(\mathrm{P}_{1}-\mathrm{P}_{0}\right)+\mathrm{Div}}{\mathrm{P}_{0}}-\mathrm{Me}_{\mathrm{RI}}
$$

Sumber: Widarto (2015)

Dimana:

EcP : Economic Performance (Kinerja Ekonomi)

$P_{1} \quad$ : Harga saham akhir tahun

$P_{0} \quad$ : Harga saham awal tahun

Div : Pembagian deviden

$M e_{R I}$ : Median return saham tahunan (annual stock return median).

\section{Business Strategy (Variabel Independen)}

Business strategy di klasifikasikan menjadi empat tipe strategi yaitu prospector, defender, analyzer dan reactor menurut definisi Miles et al. (1978). Penelitian ini menggunakan enam proxy untuk mengukur business strategy perusahaan yang didesain untuk dinilai atau diberikan skor agar merefleksikan business strategy yang digunakan perusahaan. Untuk memperoleh nilai strategi, penelitian ini menggunakan pengukuran dari penelitian Bentley et al (2017), yaitu:

1. RnD Intens

$$
\text { RnD Intens }=\frac{R n D \text { Expense }}{\text { Sales }}
$$

2. Sales Effort

$$
\begin{array}{|c|}
\hline \text { Sellina aeneral and Admin expense } \\
\hline \text { Employee Intensity }=\frac{\text { Number of Employees }}{\text { Sales }} \\
\hline
\end{array}
$$

3. Employee Intensity

\section{Capital Intensity}

$$
\text { Capital Intensity }=\frac{\text { Property, } \text { Plant and Equipment }}{\text { Total Asset }}
$$

\section{Employee Fluctuation}

6. Sales Growth

Menurut Widyasari et al (2017), Setiap komponen diranking per tahun - per perusahaan dan diberi skor berdasarkan kuintilnya. Sampel

$$
\text { Sales Growth }=\frac{\text { Sales } t-\text { Sales } t-1}{\text { Sales } t-1}
$$

perusahaan yang berada pada urutan kuintil teratas memperoleh skor 5, sampel perusahaan yang berada pada urutan dibawahnya memperoleh skor 4 , begitu dan seterusnya. Cara penilaian ini diberikan untuk semua komponen kecuali Capital Intensity. Komponen tersebut diberi penilai secara terbalik. Selanjutnya skor ranking tersebut dijumlah, sehingga setiap observasi mempunyai nilai minimum 1 dan maksimum 30. Sesuai (Bentley-Goode et al., 2017) perusahaan dapat dikategorikan sebagai defender apabila rata-rata peringkat perusahaan untuk 6 ukuran variabel berada pada kuintil paling rendah (nilai 1 atau 2), atau memiliki total skor pada range minimum 6 sampai dengan 12. Sebaliknya, perusahaan dikategorikan sebagai prospector apabila rata-rata peringkat perusahaan untuk 6 ukuran variabel berada pada kuintil paling tinggi (bernilai 5 atau 4), atau memiliki total skor pada range 24 sampai maksimum 30. Perusahaan yang dikategorikan sebagai analyzer memiliki total skor pada range 13 sampai dengan 23 (Bentley-Goode et al., 2017). Apabila perusahaan memiliki total skor diluar range yang telah disebutkan diatas, maka akan dikategorikan sebagai reactor, yaitu memiliki total skor pada range 1-5.

\section{Knowledge Management (Variabel Independen)}

Knowledge management diukur menggunakan indeks knowledge management yang telah disusun berdasarkan teori dari berbagai sumber sehingga menghasilkan pengembangan pengukuran terbaru. Indeks Knowledge Management terdiri dari 4 dimensi yaitu, Balance Scorecard, Benchmarking, Metode Rumah Kualitas dan RMAF (Result-based management and accountability framework). Itemitem yang ada di indeks knowledge management bisa dilihat dalam annual report perusahaan atau bisa melihat informasi yang tersedia didalam website perusahaan.

Dari masing-masing item yang ada di indeks tersebut akan diberikan nilai (score), dimana 
perusahaan akan diberikan nilai 1 jika perusahaan tersebut memenuhi item yang ada di indeks knowledge management, dan nilai 0 jika perusahaan tersebut tidak memenuhi item yang ada di indeks knowledge management. Setelah pemberian nilai (scoring) pada indeks knowledge management selesai dilakukan, maka besarnya disclosure level dapat ditentukan dengan rumus sebagai berikut:

\section{Corporate Social Performance (Variabel Independen)}

Menurut (Fauzi, 2009), Konsep kinerja sosial perusahaan (Corporate Social Performance) yaitu bahwa kinerja sosial perusahaan identik dengan tanggung jawab sosial perusahaan (Corporate Social Responsibility/ CSR) dan menyeimbangkannya dengan performance keuangan. Performance keuangan dimaksudkan disini adalah net profit atau laba bersih perusahaan. Karena laba bersih perusahaan berpengaruh terhadap tingkat pengungkapan tanggung jawab sosial perusahaan. Hubungan antara laba bersih perusahaan dengan tanggung jawab sosial perusahaan sudah menjadi anggapan dasar, sehingga semakin tinggi laba yang didapat maka semakin besar pengungkapan informasi sosial perusahaan (Hackston \& Milne, 1996).

Bahwa dikaitkannya antara CSR dengan net profit untuk memberikan suatu penjelasan apakah kinerja sosial perusahaan yang sudah dilakukan sesuai dengan kondisi lingkungan sosial yang sebenarnya terhadap laba yang dihasilkan. Dengan demikian, rumus yang digunakan untuk mengetahui kinerja sosial perusahaan dapat diukur dengan dua pendekatan. Pendekatan pertama dari konsep tanggung jawab sosial perusahaan diproksikan dengan CSRD (Corporate Social Responsibility Disclosure) dan pendekatan kedua menggunakan

\begin{tabular}{llll}
\hline \hline R-squared & 0.182589 & Mean dependent var & 7.481890 \\
Adjusted R-squared & 0.148051 & S.D. dependent var & 0.799625 \\
S.E. of regression & 0.738063 & Sum squared resid & 38.67629 \\
F-statistic & 5.286552 & Durbin-Watson stat & 1.001522 \\
Prob(F-statistic) & 0.002394 & & \\
\hline \hline
\end{tabular}

rumus logaritma natural (Ln) net profit.

Pendekatan pertama dari konsep tanggung jawab sosial perusahaan diproksikan dengan CSRD (Corporate Social Responsibility Disclosure)

$$
C S R D=\frac{\sum \text { Kriteria Pengungkapan Perusahaan }}{\sum \text { Kriteria Pengungkapan Sesuai GRI G4 }}
$$

berdasarkan indikator Global Reporting Initiatives (GRI) G4. GRI G4 terdapat 91 kriteria yang mencakup semua dimensi. Jika perusahaan mengungkapkan aktivitas CSR sesuai kriteria, maka akan diberi skor 1 (satu). Sedangkan jika tidak maka diberi skor 0 (nol).

1. CSRD (Corporate Social Responsibility Disc)

$$
C S P=\frac{\text { Corporate Social Responsibility Disc }}{\text { Ln Net Profit }}
$$

Pendekatan kedua menggunakan rumus logaritma natural (Ln) net profit, Penggunaan logaritma natural (Ln) net profit dikarenakan setiap perusahaan memiliki besaran net profit berbedabeda untuk menghindari data yang tidak normal. Sehingga corporate social performance dapat

$$
\mathrm{EP}=\mathrm{a}+\beta 1 \mathrm{BSit}+\beta 2 \mathrm{KM} i t+\beta 3 \mathrm{CSP} i t+\varepsilon_{\mathrm{it}}
$$

dihitung dengan rumus berikut:

\section{CSP (Corporate Social Performance)}

\section{Teknik Analisis Data}

Analisis dalam penelitian ini menggunakan analisis regresi data panel, dengan bantuan softwere pengolah data statistic yaitu Eviews 9.0. Model regresi data panel dapat ditulis sebagai berikut:

Keterangan:

$$
\begin{aligned}
& \mathrm{EP} \quad=\text { Economic Performance } \\
& \text { a } \quad=\text { Konstanta } \\
& \beta 1 \beta 2 \beta 3=\text { Koefisien regresi variabel independen } \\
& \mathrm{BS} \quad=\text { Business Strategy } \\
& \text { KM = Knowledge Management } \\
& \text { CSP = Corporate Social Performance } \\
& \text { i } \quad=\text { Perusahaan } \\
& \mathrm{t} \quad=\text { Tahun } \\
& \text { e } \quad=\text { Koefisien Error }
\end{aligned}
$$

\section{HASIL DAN PEMBAHASAN \\ Uji Kelayakan Model (Model Fit Test)}

Uji kelayakan model dilakukan untuk menentukan jika variabel independen ditambahkan ke dalam model apakah secara signifikan memperbaiki 
model fit. Atau dengan kata lain model penelitian ini layak atau tidak untuk dilanjutkan. Hasil uji kelayakan model menunjukan bahwa nilai $F$-statistic sebesar 5.286552, sementara F Tabel dengan tingkat $\alpha=5 \%$, dfl $(\mathrm{k}-1)=3$ dan df $2(\mathrm{n}-\mathrm{k})=71$ didapat nilai F Tabel sebesar 2.50. Dengan demikian F-statistic (5.286552) > F Tabel (2.50) dan nilai $\operatorname{Prob}(F$ statistic) adalah 0.002394. Dapat diartikan bahwa secara bersama-sama variabel independen dalam penelitian ini yaitu business strategy, knowledge management dan corporate social performance berpengaruh terhadap economic performance. Sehingga model ini dapat dikatakan fit dan layak untuk dilanjutkan.

\section{Koefisien Determinasi}

\begin{tabular}{|llll|}
\hline R-squared & 0.182589 & Mean dependent var & 7.481890 \\
Adjusted R-squared & 0.148051 & S.D. dependent var & 0.799625 \\
\hline
\end{tabular}

Nilai koefisien determinasi pada penelitian ini ditunjukan dengan nilai Adjusted $R$-Square. Nilai Adjusted $R$-Square digunakan untuk mengukur seberapa besar variabel dependen yang dapat dijelaskan oleh variabel independen. Semakin besar hasil Adjusted $R$-square akan semakin baik karena hal ini mengidentifikasi semakin baik variabel independen dalam menjelaskan variabel dependen. Nilai Adjusted-R-Square sebesar 0.148051 menunjukan kesesuaian atau kecocokan terhadap model yang berarti model mampu menjelaskan hubungan antara variabel dependen dan variabel independen. Artinya, bahwa perubahan naik turunnya Economic Performance (EP) dapat dijelaskan oleh business strategy, knowledge management dan corporate social performance sebesar $14.80 \%$, sedangkan sisanya sebesar $85.20 \%$ dijelaskan oleh variabel-variabel lain diluar model penelitian.

\section{Uji Hipotesis (Uji t)}

Pengujian signifikansi parsial (Uji t) dilakukan untuk mengetahui pengaruh variabel independen terhadap variabel dependen. Variabel independen dikatakan signifikan terhadap variabel dependen apabila nilai significant lebih kecil jika dibandingkan dengan tingkat alpha $(\alpha) 0.05$.

\begin{tabular}{crrrr}
\hline \hline Variable & Coefficient & Std. Error & t-Statistic & Prob. \\
\hline \hline C & 15.53394 & 1.127396 & 13.77860 & 0.0000 \\
SB & -0.012698 & 0.036440 & -0.348471 & 0.7285
\end{tabular}

$\begin{array}{lllll}\text { KM } & 3.924414 & 1.313571 & 2.987591 & 0.0039\end{array}$

$\begin{array}{lllll}\text { CSP } & 64.10785 & 55.61101 & 1.152791 & 0.2529\end{array}$

Berdasarkan hasil uji t diatas menunjukan bahwa:

1. Nilai Prob. BS sebesar $0.7285>0.05$ maka dapat disimpulkan bahwa variabel Business strategy dalam penelitian ini tidak memiliki pengaruh terhadap economic performance (EP). Dengan demikian, $\mathrm{H}_{1}$ dalam penelitian ini ditolak.

2. Nilai Prob. KM sebesar $0.0039<0.05$ maka dapat disimpulkan bahwa variabel Knowledge Management dalam penelitian ini memiliki pengaruh positif terhadap economic performance (EP). Dengan demikian, $\mathbf{H}_{2}$ dalam penelitian ini diterima.

3. Nilai Prob. CSP sebesar $0.2529>0.05$ maka dapat disimpulkan bahwa variabel Corporate Social Performance dalam penelitian ini tidak memiliki pengaruh terhadap economic performance (EP). Dengan demikian, $\mathbf{H}_{3}$ dalam penelitian ini ditolak.

\section{Analisis Regresi Data Panel}

Hasil perhitungan analisis regresi data panel dalam penelitian ini diperoleh persamaan regresi sebagai berikut:

$\begin{aligned} \mathrm{EP}= & 15.53394-0.012698 S B+3.924414 K M+ \\ & 64.10785 C S P+\varepsilon i t\end{aligned}$

Berdasarkan persamaan regresi data panel diatas dapat diinterpretasikan bahwa:

a. Konstanta sebesar 15.53394. Hal ini mengindikasikan bahwa jika tidak terdapat nilainilai pada variabel independen (variabel-variabel independen sama dengan 0), maka economic performance memiliki nilai sebesar 15.53394.

b. Nilai koefisien variabel business strategy (BS) sebesar -0.012698 berarti bahwa setiap peningkatan 1 (satu) satuan business strategy (BS) akan menurunkan sebesar 0.012698 dengan asumsi variabel independen lainnya bernilai konstan (tetap).

c. Nilai koefisien variabel knowledge management sebesar 3.924414, berarti bahwa setiap peningkatan 1 (satu) satuan knowledge management maka economic performance akan meningkat sebesar 3.924414 dengan asumsi variabel independen lainnya bernilai konstan (tetap). 
d. Nilai koefisien variabel corporate social performance sebesar 64.10785 , berarti bahwa setiap peningkatan 1 (satu) satuan corporate social performance maka economic performance akan meningkat sebesar 64.10785 dengan asumsi variabel independen lainnya bernilai konstan (Tetap).

\section{Pembahasan \\ Pengaruh Business Strategy Terhadap Economic Performance}

Penyebab Business Strategy tidak berpengaruh dapat dijelaskan bahwa untuk menilai strategi bisnis suatu perusahaan berkaitan dengan bagaimana bersaing pada pasar produk/jasa yang telah diputuskan untuk dimasuki. Strategi bisnis yang digunakan perusahaan yaitu agar mampu beradaptasi menghadapi lingkungan yang kompetitif.

Hasil penelitian ini memberikan arti bahwa berdasarkan tipe strategi yang dimiliki, perusahaan tidak siap menghadapi perkembangan yang terjadi sehingga semakin tinggi strategi suatu perusahaan tersebut tidak menjadi tolak ukur perusahaan untuk peningkatan kinerja ekonominya, begitupun sebaliknya semakin rendah strategi bisnis suatu perusahaan tidak memberikan jaminan perusahaan memiliki kinerja ekonomi yang rendah pula. Dari analisa yang dilakukan, dapat disimpulkan bahwa business strategy tidak berpengaruh karena tidak adanya keterkaitan didalam strategi bisnis yang dilakukan oleh perusahaan manufaktur dengan tingkat pengembalian saham dan juga tidak mempengaruhi perubahan harga saham perusahaan yang bersangkutan, karena dengan tingkat pengembalian saham yang rendah tidak dapat meningkatkan kinerja ekonomi suatu perusahaan, tingkat pengembalian saham yang rendah akan mengakibatkan kurangnya daya tarik investor untuk melakukan investasi.

Hasil penelitian ini sesuai dengan penelitian yang dilakukan oleh (Paylosa, 2014) yang menyatakan bahwa Business Strategy tidak berpengaruh terhadap Kinerja Perusahaan.

\section{Pengaruh Knowledge Management Terhadap Economic Performance}

Hal ini dapat dijelaskan bahwa sebuah organisasi sangat dipengaruhi oleh sumber daya pengetahuan. Dimana pengetahuan itu akan menjadi aset sebuah organisasi dalam perusahaan yang akan memunculkan ide-ide baru sehingga peran knowledge management semakin penting dalam perusahaan karena sebagai alat untuk memfasilitasi interaksi yang lebih baik melalui ketersediaan arus informasi, hal ini baik guna meningkatkan kinerja ekonomi dalam perusahaan.

Hasil ini mendukung teori stakeholder yaitu suatu teori yang mengatakan bahwa keberlangsungan suatu perusahaan tidak terlepas dari adanya peranan stakeholder baik dari internal maupun eksternal dengan berbagai latar belakang kepentingan yang berbeda. Pihak stakeholder internal berperan aktif mengelola manajemen perusahan agar dengan keikutsertaannya dalam mengelola manajemen pengetahuan dan meningkatkan mutu pengetahuan di dalam organisasi itu sendiri sehingga dapat meningkatkan kinerja ekonomi. Dengan meningkat nya kinerja ekonomi akan mempengaruhi stakeholder dari eksternal sehingga stakeholder eksternal yakin bahwa perusahaan tersebut bisa bersaing dalam era globalisasi seperti saat ini dan dapat berpartisipasi dalam mengembangkan knowledge management diperusahaan agar tercapainya tujuan. Dengan begitu indeks knowledge management yang telah disusun berdasarkan teori-teori yang ada dapat merepresentasikan knowledge management secara umum didalam sebuah perusahaan.

\section{Pengaruh Corporate Social Performance Terhadap Economic Performance}

Penyebab Corporate Social Performance tidak berpengaruh salah satu faktor yang paling dominan karena masih banyaknya perusahaan yang tidak mengungkapkan secara keseluruhan mengenai item yang ada didalam pedoman GRI G4 yang sebenarnya hal tersebut jika diungkapkan akan sangat baik efeknya terhadap transparansi perusahaan yang akan meningkatkan kinerja ekonomi perusahaan. Faktor lainnya seperti pengeluaran biaya tambahan untuk menunjang kegiatan tersebut, menjadikan biaya yang dikeluarkan lebih besar dan mengganggu besaran laba perusahaan sehingga untuk meningkatkan kinerja ekonomi diperusahaan akan lebih sulit.

Hasil penelitian ini sesuai dengan penelitian yang dilakukan oleh (Wibisono et al., 2014) yang menyatakan bahwa Corporate Social Performance 
tidak berpengaruh terhadap Kinerja Keuangan Perusahaan.

\section{DAFTAR PUSTAKA}

Adams, C. A. (2002). Internal organisational factors influencing corporate social and ethical reporting. Accounting, Auditing \& Accountability Journal, 15(2), 223-250. https://doi.org/10.1108/09513570210418905

Ajagbe, M. A., Peter, O. F., Udo Udo, E. E., Uduimoh, A. A., \& Akpan, S. E. (2016). Business Strategy As A Contributor To Organizational Performance. International Journal of Advanced Academic Research, 2(3), $1-19$.

Al-Tuwaijri, S. A., Christensen, T. E., \& Hughes, K. E. (2004). The relations among environmental disclosure, environmental performance, and economic performance: A simultaneous equations approach. Accounting, Organizations and Society, 29(5-6), 447-471. https://doi.org/10.1016/S0361-3682(03)000321

Alavi, M., \& Leidner, D. (1999). Knowledge Management Systems: Issues, Challenges, and Benefits. Communications of the Association for Information Systems, 1(February). https://doi.org/10.17705/1cais.00107

Andayani, R. (2015). Hubungan antara ISO 140001, Environmental Performance dan Environmental Disclosure Terhadap Economic Performance. Jurnal Akuntansi Dan Sistem Teknologi Informasi, 11(2), 186-193.

Basuki, Agus Tri dan Prawoto, Nano. (2017). Analisis Regresi Dalam Penelitian Ekonomi \& Bisnis: Dilengkapi Aplikasi SPSS \& EVIEWS. Depok: PT Rajagrafindo Persada

Beaver, W. H. (1968). The Information Content of Annual Earnings Announcements. Journal of Accounting Research, 6, 67. https://doi.org/10.2307/2490070

Bentley-Goode, K. A., Omer, T. C., \& Twedt, B. J. (2017). Does Business Strategy Impact a Firm's Information Environment? Journal of Accounting, Auditing \& Finance. https://doi.org/10.2139/ssrn.2162240

Carroll, A. B. (1979). A Three-Dimensional Conceptual Model of Corporate Performance. Academy of Management Review, 4(4), 497505. https://doi.org/10.5465/amr.1979.4498296

Clarkson, M. B. E. (1995). A Stakeholder Framework for Analyzing and Evaluating Corporate Social Responsibility. The Academy of Management Review, 20(1), 92-117.

Cohen, M. S., Bowers, W. C., Aronson, H., \& Gray,
E. T. (1987). Cell-Free Solubilization of Coal by Polyporus versicolor. 53(12), 2840-2843.

Dalkir, K. (2005). Knowledge Management in Theory and Practice. United States America: Elsevier B.V.

Darroch, J. (2003). Developing a measure of knowledge management behaviors and practices. Journal of Knowledge Management, $7(5)$, 41-54. https://doi.org/10.1108/13673270310505377

Donaldson, L., \& Davis, J. H. (1991). Stewardship Theory or Agency Theory: CEO Governance and Shareholder Returns. Australian Journal of Management, 16(1), 49-64. https://doi.org/10.1177/031289629101600103

Eduardus, E., \& Juniarti. (2016). Kinerja Sosial Perusahaan dan Kinerja Keuangan Perusahaan yang Diukur Menggunakan Tobin' s q. Business Accounting Review, 4, 517-528.

Effendi, M. (2017). Analisis Risiko Sistematis dan Risiko Tidak Sistematis Terhadap Expected Return Saham Dalam Pembentukan Portofolio Optimal Indeks Saham LQ45. Jurnal Manajerial Bisnis, 1, 178-193.

Eksandy, A. (2018). Komunikasi akuntansi untuk perusahaan dagang : dilengkapi contoh praktik penyusunan laporan keuangan menggunakan program akuntansi accurate. Fakultas Ekonomi dan Bisnis Universitas Muhammadiyah Tangerang.

Eksandy, A. (2018). Metode penelitian akuntansi dan manajemen: dilengkapi contoh penelitian data sekunder dan data primer dengan analisis regresi data panel dan analisis regresi linear berganda.

Eksandy, A. (2018). Pengaruh Audit Tenure, Ukuran Perusahaan, Profitabilitas, Leverage Dan Komite Audit Terhadap Manajemen Laba (Studi Pada Perusahaan Jasa Subsektor Perdagangan Besar Barang. Konferensi Akuntansi Banten 1 (KAB-1) "Peran Stakeholder Dalam Mewujudkan Laporan Keuangan Pemerintahan Daerah Yang Transparan dan Akuntabel." IAI KAPd Banten.

Eksandy, A. (2018). Pengaruh Good Corporate Governance Terhadap Kinerja Keuangan Pada Perbankan Syari'ah Indonesia. JAK (Jurnal Akuntansi): Kajian Ilmiah Akuntansi, 5(1), 1. https://doi.org/10.30656/jak.v5i1.498

Eksandy, A. (2018). Pengaruh Perputaran Modal Kerja , Perputaran Piutang Dan Perputaran Kas Terhadap Profitabilitas Perusahaan ( Studi Pada Perusahaan Konstruksi Sektor Infrastruktur Di 
Bursa Efek Indonesia Periode 2012 - 2015 ). Jurnal Dinamika UMT, 2(2), 1-14.

Eksandy, A. (2019). Pengaruh Komisaris Independen, Komite Audit, dan Kualitas Audit terhadap Penghindaran Pajak (Tax Avoidance). Competitive Jurnal Akuntansi Dan Keuangan, 1(1), 1-20.

Eksandy, A., Frederica, D., Dwianika, A., Nusdal, J., \& Hamzah, M. Z. (2017). Company Value Determinant Implementation The Corporate Governance Of Incorporated Company Issues (Year 2014-2016 LQ45). In EMAN-AP 2017 "Environmental and Sustainability Management Acccounting for The Development of Sustainablity and Accountanbility: "Should We Talk Beyon Number?"

Eksandy, A., Frederica, D., Dwianika, A., Nusdal, J., \& Hamzah, M. Z. (2018). The Firm's Determinant Value On Corporate Governance Implementation For Incorporated Company Issues (Year 2014-2016 LQ45). Research Gate.

Eksandy, A., \& Hakim, M. Z. (2018). Faktor-Faktor Yang Berpengaruh Terhadap Pengungkapan Islamic Social Reporting pada Perbankan Syari'ah Indonesia Periode 2011-2015. Jurnal Akuntansi Maranatha, 10(2), 187-198. https://doi.org/10.28932/jam.v10i2.1084

Eksandy, A., Hakim, M. Z., \& Ekawati. (2018). Pengaruh Pendapatan Asli Daerah, Dana Alokasi Umum, dan Dana Alokasi Khusus Terhadap Belanja Modal (Pada Pemerintah Provinsi Banten Periode 2011-2015). Competitive Jurnal Akuntansi Dan Keuangan, 2(2), 85-94. Retrieved from http://jurnal.umt.ac.id/index.php/competitive/ar ticle/view/917/582

Eksandy, A., \& Hakim, Z. M. (2017). Pengaruh Ukuran Perusahaan, Profitabilitas, dan Leverage Terhadap Pengungkapan Islamic Social Reporting (ISR). Seminar Nasional dan The 4th Call For Syariah Paper (SANCALL) 2017 "Peran Profesi Akuntansi Dalam Penaggulangan Korupsi." (pp. 47-59).

Eksandy, A., \& Heriyanto, F. (2018). Metode penelitian akuntansi dan keuangan : dilengkapi analisis regresi data panel dan logistik data panel menggunakan program EViews. Fakultas Ekonomi dan Bisnis Universitas Muhammadiyah Tangerang.

Eksandy, A., \& Milasari, E. (2019). Pengaruh Environmental Disclosure, Kualitas Auditor Internal, Dan Kontrak Manajemen Terhadap
Kualitas Laba (Pada Perusahaan Indeks Kompas 100 yang Terdaftar di Bursa Efek Indonesia Periode 2013-2016). Competitive Jurnal Akuntansi Dan Keuangan, 3(1), 88-113.

Fauzi, H. (2009). The Relationship of CSR and Financial Per- formance: New Evidence from Indonesian Companies. Issues in Social and Environmental Accounting, 3(1), 66-87.

Freeman, R. E., \& Reed, D. L. (1983). Stockholders and Stakeholders: A New Perspective on Corporate Governance. XXV(3), 88-106.

Hackston, D., \& Milne, M. J. (1996). Some determinants of social and environmental disclosures in New Zealand companies. Accounting, Auditing \& Accountability Journal, 9(1), 77-108. https://doi.org/10.1108/09513579610109987

Haholongan, R. (2016). Kinerja Lingkungan dan Kinerja Ekonomi. 19(3), 413-423.

Hakim, M. Z., \& Eksandy, A. (2017). Pengaruh Likuiditas, Leverage Dan Profitabilitas Terhadap Stock Price Pada Industri Manufaktur. Competitive, 2(2), 66-84.

Houqe, M. N., Kerr, R., \& Monem, R. (2013). Business Strategy and Earnings Quality. (92).

Ikujiro Nonaka Noboru Konno. (1998). The Concept of "Ba": Building a Foundation for Knowledge Creation. 40.

Kusuma, I. G. A., Mendra, I. W., \& Anggraini, N. P. N. (2014). Pengaruh Kinerja Ekonomi dan Kinerja Lingkungan Terhadap Corporate Social Responsibility Pada Perusahaan Manufaktur Yang Terdaftar di Bursa Efek Indonesia (20102012). Jurnal Ilmu Manajemen, 4(2).

Kyobe, M. (2010). A knowledge management approach to resolving the crises in the information systems discipline. Journal of Systems and Information Technology, 12(2), 161-173. https://doi.org/10.1108/13287261011042949

Lesmana, Y., \& Tarigan, J. (2014). Pengaruh Sustainability Reporting Terhadap Kinerja Keuangan Perusahaan Publik dari Sisi Asset Management Ratios. Business Accounting Review, 2(1), 101-110.

Lin, C., Tsai, H. L., \& Wu, J. C. (2014). Collaboration strategy decision-making using the Miles and Snow typology. Journal of Business Research, 67(9), 1979-1990. https://doi.org/10.1016/j.jbusres.2013.10.013

Miles, R. E., Snow, C. C., Meyer, A. D., Coleman, H. J., Miles, R. E., Snow, C. C., \& Meyer, A. D. (1978). Organizational Strategy , Structure ,. 3(3), 546-562.

Nugroho, I., \& Sukhemi. (2015). Pengaruh Risiko Sistematis dan Likuiditas Terhadap Return 
Saham Pada Perusahaan Manufaktur. Jurnal Akuntansi, 3(2), 63-74.

Paylosa, F. (2014). Pengaruh Strategi Bisnis dan Desentralisasi Terhadap Hubungan Antara Pemanfaatan Informasi Sistem Akuntansi Manajemen dan Kinerja Manajerial.

Pinatih, L. P. W. K., \& Lestari, P. V. (2014). Return Saham Perusahaan Otomotif Di BEI. 29903002.

Polanyi, M. (1958). Personal Knowledge (First). London: Taylor \& Francis e-Library.

Porter, M. E. (1985). Creating and sustaining competitive advantage: Management logics, business models, and entrepreneurial rent. In Creating and Sustaining Competitive Advantage: Management Logics, Business Models, and Entrepreneurial Rent. https://doi.org/10.1007/978-3-319-54540-0

Prabandari, K. R., \& Suryana, K. (2014). Pengaruh Environmental Performance Pada Reaksi Investor Di Perusahaan High Profile Bursa Efek Indonesia. E-Jurnal Akuntansi Universitas Udayanauntansi, 2(7.2), 299-312.

Puspita, A. M. (2018). Pengaruh Strategi Bisnis Terhadap Kinerja Perusahaan Dengan Manajemen Laba Sebagai Variabel Intervening.

Putra, D., \& Utami, I. L. (2017). Pengaruh Environmental Performance Terhadap Environmental Disclosure dan Economic Performance ( Studi Empiris pada Perusahaan Pertambangan yang Terdaftar Di BEI ). Jurnal Akuntansi, 9(1), 1-11.

Rizky, R. (2016). Pengaruh Environmental Performance terhadap Economic Performance. IOSR Journal of Economics and Finance, 3(1), 56. https://doi.org/https://doi.org/10.3929/ethzb-000238666

Rosyid, A. (2015). Pengaruh Kinerja Sosial dan Kinerja Lingkungan Terhadap Kinerja Keuangan. 12(40), 72-85.

Sahas, A., \& Falah, N. (2017). Pengaruh Knowledge Management Terhadap Kinerja Karyawan Dan Kinerja Perusahaan ( Studi pada Karyawan PT Semen Indonesia Persero Tbk ). Jurnal Administrasi Bisnis, 50(4), 192-198.

Salama, I. E. E. (2017). The Impact of Knowledge Management Capability, Organizational Learning, and Supply Chain Management Practices on Organizational Performance. International Journal of Business and Economic Development (IJBED), 5(1), 71-85. Retrieved from https://search.proquest.com/docview/19341537 85 ?accountid $=27934$

Sarac, M., Ertan, Y., \& Yucel, E. (2014). How Do
Business Strategies Predict Firm Performance? An Investigation On Borsa Istanbul 100 Index. The Journal of Accounting and Finance, 61(1), 121-134.

Sugiyono. (2017). Metode Penelitian Kuantitaf, Kualitatif dan $R \& D$ (25th ed.). Bandung: Alfabeta, CV.

Sule, E. T., \& Saefullah, K. (2017). Pengantar Manajemen (Edisi Pert).

Sunusi, S. A. (2018). Evaluasi Creative Accounting dalam Pelaporan Keuangan Berdasarkan Perspektif Akuntansi Positif. 1-86. Retrieved from http://repositori.uinalauddin.ac.id/1178/1/rezki.pdf?cv=1

Tristianasari, G., \& Fachrurrozie. (2014). Analisis Economic Performance Perusahaan. Accounting Analysis Journal, 3(2), 135-146.

Tung, K. Y. (2018). Memahami Knowledge Management (Cetakan I; B. Sarwiji, Ed.). Jakarta: INDEKS.

Vivianita, A., \& Nafasati, F. (2016). Pengaruh Environmental Performance Terhadap Kinerja Keuangan Dengan Corporate Governance Sebagai Variabel Pemoderasi. Jurnal REP (Riset Ekonomi Pembangunan), 03(01), 295305.

Wardani, D. K., \& Isbela, P. D. (2017). Pengaruh Strategi Bisnis dan Karakteristik. Jurnal Riset Akuntansi Dan Keuangan, (1), 91-106.

Wartick, S. L., \& Cochran, P. L. (1985). The Evolution of the Corporate Social Performance Model. Academy of Management Review, 10(4), $\quad$ 758-769. https://doi.org/10.5465/amr.1985.4279099

Watts, R. L., \& Zimmerman, J. L. (1990). Accounting Year Theory: Ten Perspective. The Accounting Review, 65(1), 131-156. https://doi.org/10.2307/247880

Wibisono, M., Darmadji, S. H., \& Sutanto, A. C. (2014). Hubungan antara. Jurnal Ilmiah Mahasiswa Universitas Surabaya, 3(1), 535542.

Widarto, D., \& Mudjiyanti, R. (2015). Pengaruh Environmental Performance dan Environmental Disclosure Terhadap Economic Performance. XV(2).

Widyasari, P. A., Harindahyani, S., \& Rudiawarni, F. A. (2017). Strategi Bisnis dalam Praktik Manajemen Laba pada Perusahaan Manufaktur di Indonesia. Jurnal Keuangan Dan Perbankan, 21(3), 397-411. https://doi.org/10.26905/jkdp.v21i3.1179

Wiig, K. M. (1993). Knowledge management. In Advances in Psychiatric Treatment (Vol. 8). https://doi.org/10.1192/apt.8.5.387

Williams, G. (2019). Knowledge Management 
Maturity and MNC Performance as Measured by Economic Value Added ( EVA ). $X I V($ December $)$.

Winarno, W. W. (2015). Analisis Ekonometrika dan Statistik dengan EViews (Edisi Keem). Yogyakarta.

Wirawan, W. P. (2016). Analisis Hubungan Corporate Social Performace ( CSP ) dengan Kinerja Keuangan Bank Syariah Yang Terdaftar di OJK (Otoritas Jasa Keuangan).

Wood, D. J., \& Gray, B. (1991). Toward a Comprehensive Theory of Collaboration (pp. 139-162). pp. 139-162.

Wulantika, L. (2017). Knowledge Management Dalam Meningkatkan Kreasi dan Inovasi Perusahaan. Majalah Ilmiah UNIKOM, 10(2), 263-270.

www.finance.yahoo.com/

www.idx.co.id/

www.sahamok.com/

Zoelisty, C., \& Adityawarman. (2014). Amanah Sebagai Konsep Pengendalian Internal Pada Pelaporan Keuangan Masjid (Studi Kasus pada Masjid di Lingkungan Universitas Diponegoro). Diponegoro Journal of Accounting, 3 (3), 1-12. Retrieved from http://ejournals1.undip.ac.id/index.php/accounti ng 